\title{
İNTRAABDOMINAL İNFEKSIYYONLAR
}

\author{
F. Tansu SALMAN ${ }^{1}$, Tutku SOYER ${ }^{2}$
}

${ }^{1}$ İstanbul Üniversitesi İstanbul Tıp Fakültesi, Çocuk Cerrahisi Anabilim Dalı, İSTANBUL

${ }^{2}$ Kırıkkale Üniversitesi Tıp Fakültesi, Çocuk Cerrahisi Anabilim Dalı, KIRIKKALE

ÖZET

Intraabdominal infeksiyonlar (IAI) akut apandisit gibi basit bir abdominal infeksiyondan ciddi sonuçlarn olan barsak infarktına kadar uzanan heterojen bir grup cerrahi alan infeksiyonunu tanımlar. İI'lar toplumdan kaynaklı veya sağllk baklmı ile ilişkili olabilir. İİ olan hastalarda erken tanı, kaynak kontrolü ve uygun amprik tedavi ile morbidite ve mortalite önlenebilir. Bu yazıda erişkin ve çocuklarda gözlenen IAI'larn tanı ve tedavi özellikleri güncel rehberler ışı̆̆ında derlenmeye çalışılmıştır.

Anahtar sözcükler: ampirik tedavi, çocuklar, erişkin, intraabdominal infeksiyon

\section{SUMMARY}

\section{Intraabdominal Infections}

Intraabdominal infections (IAI) defined a heteregous group of surgical site infections ranging from a simple abdominal infection such as acute appendicitis, to an intestinal infarct with severe consequences. IAI may be seen either community acquired or health-care related. Mortality and morbidity can be prevented by early diagnosis, source control and appropriate ampric treatment. It is aimed to review the diagnostic and treatment features of IAI in adults and children with the light of current guidelines.

Keywords: adults, ampric treatment, children, intraabdominal infection

İntraabdominal infeksiyon (İAं), barsakların perforasyon veya yırtılması sonucu bakterilerin peritoneal kaviteye veya retroperitonyuma yayılması olarak tarif edilebilir. Karın içine dağılan bakteriler peritonite ve apse oluşumuna yol açarlar. Peritonit, intraperitoneal supüratif infeksiyon sonucu oluşan pariyatal ve visseral peritonun inflamasyon halidir.

Burada tartışılacak İAI'daki peritonit durumu barsakların yaralanması sonucu ortaya çıkan bir sekonder peritonit durumudur. Barsak karın içine açılmaksızın görülen primer peritonitler bu konu içine alınmamıştır. Primer peritonit durumunda mikroorganizmalar kan, üriner sistem, transdiafragmatik, barsak lümeninden transmural veya kız çocuklarında daha sık görüldüğü gibi genital yolla karın içine gelebilmektedir. Primer peritonit olgularında barsak perforasyonu olmasa da, sekonder peritonitte olduğu gibi pürülan bir karın içi sıvısı görülebilir ve mikroorganizma üretilir.

Gastrointestinal kontaminasyon sonucu oluşan sekonder peritonit lokalize veya generalize olabilir. Çocuklarda en çok perfore apandisit ve yenidoğanlarda nekrotizan enterokolit (NEK) durumlarında görülür.

\section{Intraabdominal infeksiyon nedenleri}

Sekonder peritonitin yol açtığ 1 İAI'lar, barsakların nekrozu, inflamasyonu, tıkanması veya travma sonucu ortaya çıkan perforasyon ve bu defektten enteral mikroorganizmaların peritoneal kaviteye geçmesiyle oluşur. Zamanında cerrahi girişim yapılamamış ve nazogastrik dekompresyon uygulanmamış tüm intestinal obstrüksiyonlu hastalarda, tıkanmanın proksi-

\footnotetext{
İletişim adresi: F. Tansu Salman. İstanbul Üniversitesi İstanbul Tıp Fakültesi, Çocuk Cerrahisi Anabilim Dalı, İSTANBUL Tel: (0212) 5337357

e-posta: tansusalman@yahoo.com

Alındığı tarih: 21.02.2011, yayına kabul: 18.03.2011
} 
malindeki basınç artımına bağlı intestinal perforasyon görülebilir. Ayrıca, dokulara yeterli oksijenin taşınamamasına bağlı iskemi sonucu oluşan nekroz da önemli bir perforasyon nedenidir. Künt ve kesici karın travmalarında da gastrointestinal sistemin yaralanmasına bağlı perforasyon ve İAİ görülme şansı oldukça yüksektir. Erişkinlerde ve çocukluk çağında en sık görülen gastrointestinal sistem perforasyon nedenleri Tablo 1 ve 2'de gösterilmiştir.

Tablo 1. Erişkinlerde sık görülen İAI nedenleri.

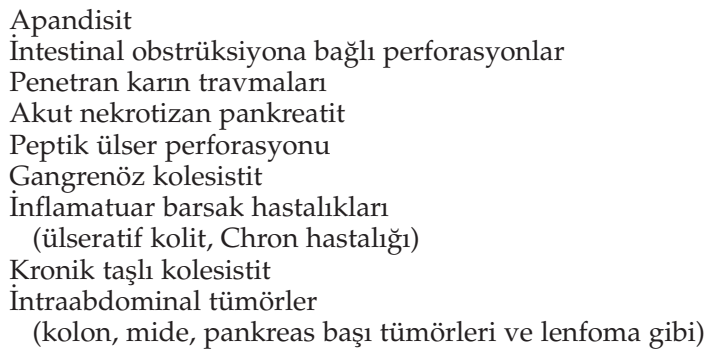

En önemli İAİ nedeni perfore apandisittir. Apandiks dokusunun iltihabı sonucu barsak duvarı kalınlaşır ve lümen daralır. Bir fekaloidin veya kiraz çekirdeği gibi bir yabancı maddenin de lümen proksimalini tıkamasıyla sekresyon lümen içinde hapis kalır (blind loop) ve iltihaplı dokunun perforasyonu kolaylaşır. Akut apandisitin pefore olmasındaki (patlamasındaki) en sik neden tanının zamanında konulamayıp, erken apandektomi yapılmamasıdır.

Yenidoğan yoğun bakım ünitelerinde özellikle prematür ve sepsisli bebeklerde nekrotizan enterokolite sık rastlanılır. Hipoksi sonucu barsakların selektif yetersiz oksijenizasyonu sonucu görülen önemli bir intestinal hastalıktır.
Barsağın tüm katlarını içine alan bir iskemi sonucu oluşan bir generalize peritonit halidir. Perforasyon riski yüksek olduğundan sık karın grafileri ile takip edilmelidir. Perforasyon halinde oluşan İAİ genellikle fatal seyreder.

Ameliyat sonrası oluşabilen perforasyon, anastomoz kaçakları ve postoperatif apse gibi komplikasyonlara bağlı olan İAI durumlarında da prognoz daha kötüye gidebilir. Bu oluşan nozokomiyal infeksiyon durumunda hem antibiyotik stratejisi hem de destek tedavi daha da önem kazanacaktır.

\section{İntestinal flora}

Mide, duodenum ve jejunum proksimalinde mikroorganizma sayısı $10^{4}$ organizma/g veya daha azken, distal ileumda $10^{8}$ organizma/g bulunmuştur. Bu değer kolonda $10^{11}$ organizma/ g'a ulaşır. Gastrointestinal sistemde distale doğru gittikçe hem mikroorganizma sayısı hem de çeşitliliği artar. Sindirim kanalının değişik bölgelerinde değişik $\mathrm{pH}$ değerleri ve değişik oksijen basincı bu farklılıklara neden olmaktadır. Asit ortamda organizmaların yaşam şansı daha az olup sayıları azalır. Örneğin midedeki düşük $\mathrm{pH}$ nedeniyle oral kavitedeki mikroorganizmaların sayısı midede azalmış olur. Ayrıca sindirim kanalının distaline doğru oksijenin azalmasıyla aerob mikroorganizmaların miktarı azalır, anaerobların sayısı $\operatorname{artar}^{(4,9)}$.

Sonuç olarak, ağızdan sindirim sistemine girmiş olan mikroorganizmalar midenin asiditesi, alt sindirim sistemdeki alkalen yapı, safranın etkisi ve distale doğru azalan oksijenle etkilenerek her seviyede belli bir dengeye ulaşır. Genel olarak gastrointestinal florada hakim bakteriler anaeroblardır. Ancak yenidoğanlarda anaerob

Tablo 2. Çocuklarda intestinal perforasyon nedenleri.

\begin{tabular}{|c|c|}
\hline İnflamasyon ve/veya iskemiye bağlı olanlar & İntestinal obstrüksiyona bağlı olanlar* \\
\hline Apandisit & Strangüle herni \\
\hline Divertükilit & İnvajinasyon \\
\hline Nekrotizan enterokolit** & Malrotasyon**(volvulus, konjenital bantlar) \\
\hline Spontan barsak veya mide perforasyon $\mathrm{u}^{* *}$ & Intestinal atrezi* \\
\hline Psödomembranöz enterokolit & Mekonyum ileus $* *$ \\
\hline Ülseratif kolit, Crohn hastalığ1 & Hirschsprung's hastalı $\breve{g}_{1}^{* *}$ \\
\hline Peptik ülser & Basıya bağlı (tümör, bant) \\
\hline İntestinal mukozal hastalıklar & Intraluminal tıkaçlar (mekonyum**, askaris, bezoar, yabancı cisim) \\
\hline
\end{tabular}

*Obstrüksiyon yanında kanlanamama sonucu iskemi nedeniyle de perforasyon olabilir.

**Daha çok yenidoğanda görülenler. 
oranı daha büyük çocuklara kıyasla daha azdır. Gastrointestinal sistemdeki mikroorganizmaların hem sayı hem de cinslerindeki farklılık perforasyon sonucu oluşacak infeksiyonun cinsini ve şiddetini belirleyecektir. Bu nedenle her seviyede intestinal floranın bilinmesi özellikle ampirik tedavi bakımından önemlidir.

\section{Intraabdominal infeksiyon etkeni mikroorga- nizmalar \\ İntraabdominal infeksiyon nedeni perfo-} rasyon olgularında peritoneal kaviteden alınan kültür çalışmaları anaerob bakterilerin çoğunlukta olduğunu göstermiştir. Perfore apandisit nedeniyle ameliyat edilmiş hastaların periton ve cerrahi yara kültürlerinde anaeroblar hakim bakterilerdir. İAI'larda en sık görülen mikroorganizma Escherichia coli'dir. Peritoneal sıvidan alınan örneklerin \% 93'ünde Bacteroides fragilis, $\%$ 43'ünde de Clostridium spp. üretilmiştir ${ }^{(13,21)}$. Perfore apandisitte elde edilen mikrobiyoloji bulguları, İAI'da sık görülen mikroorganizmalar1 yansitmaktadır ${ }^{(3,10)}$ (Tablo 3).

Brook $^{(3)}$ 'un 100 perfore apandisit olgusundan alınan örneklerin incelendiği çalışmasında, total olarak 144 aerob bakteri üretilirken, 301 anaerob bakterinin üretilmiş olması bu durumun en etkili göstergesidir. Bu çalışmada B.fragilis, Fusobacterium spp., Prevotella ve Porphyromonas spp., Gram pozitif anaerob koklar ve Clostridium spp. en sık görülen anaeroblar olarak yer almaktadır. Aeroblar içinde de E.coli, streptokoklar, enterokoklar ve Pseudomonas aeruginosa ön siralarda görülmüşlerdir. B. fragilis ve E.coli \% 43 olguda beraber bulunmuşlardır. Aynı grubun içinde görülen yara infeksiyonlarının kültürlerinde de benzer sonuçlar elde edilmiştir.

Yenidoğan döneminde İAÍa neden olan mikroorganizmaların dağılımı farklılık göstermektedir. Nekrotizan enterokolite bağlı perforasyonlarda görülen peritonitlerde, daha büyük yaşlarda görülen perforasyonlara kıyasla anaeroblar daha az görülür. Yenidoğanlarda nekrotizan enterokolite veya obstrüksiyona bağlı perforasyonlarda, en sik görülen aerobların Klebsiella, Enterobacter ve Streptococcus spp. olduğu gösterilmiştir. Bu yaşta en sık tespit edilen anaerob bakterinin ise yenidoğanların normal barsak florasında da yüksek oranda bulunan Clostridium difficile olduğu bildirilmiştir ${ }^{(11,15,17)}$.

Intraabdominal infeksiyonlarda rol oynayan mikroorganizmalar, elektif cerrahi tedavi sonrası gelişen komplikasyonlar ve acil girişimlerden sonra karşılaşılan nozokomiyal infeksiyonlarda farklılık göstermektedir. Bu durumlarda tedavisi daha güç olan dirençli bakteriler söz konusudur. Postoperatif nozokomiyal infeksiyonlarda P.aeruginosa, metisiline dirençli Staphylococcus, Proteus, enterobakterler, enterokoklar ve Candida sik görülen organizmalardir ${ }^{(12)}$.

\section{İntraabdominal infeksiyonun oluşması}

İntraabdominal infeksiyon, peritoneal kavitenin bakteriyel kontaminasyonudur. Bu kontaminasyonun da en önemli nedeni gastrointestinal sistemin perforasyonuna bağlı sekonder peritonittir. Barsak içeriğinin periton boşluğuna yayılması peritonit veya apse olarak kendini gösterir. Barsaklardaki hasarın derecesine ve bakteriyel kontaminasyonun şiddetine göre infeksiyon generalize veya lokalize olabilir.

Tablo 3. Perfore apandisitlerde sık görülen mikroorganizmalar ${ }^{(3,10)}$.

\begin{tabular}{ll}
\hline Anaerob bakteriler & Aerob bakteriler \\
\hline Gram-negatif basiller : & Gram-negatif basiller : \\
Bacterioides (en sik B.fragilis) & Escherichia coli \\
Fusobacterium & Peudomonas aeruginosa \\
Pigmente Prevotella ve Porphyromonas & Klebsiella \\
Gram-pozitif koklar : & Eikenella corrodens \\
Peptostreptococcus & Enterobacter cloacae \\
Peptococcus & Gram-pozitif koklar : \\
Gram-pozitif basiller : & Alfa-hemolitik streptokoklar \\
Clostridium & Gama-hemolitik streptokoklar \\
Propionibacterium acnes & Enterococcus
\end{tabular}


Peritonun infekte olmasiyla peritonit durumu başlar ve bakterilerin belli bölgelerde daha çok toplanmasıyla da apse gelişir. Apse formasyonunda aerobik ve anaerobik bakteri karışımı gerekir ki, barsak perforasyonlarında da bu ortam oluşmaktadır. Bu polimikrobiyal karışıma polimorfonükleer hücrelerin de eklenmesiyle apse oluşur. Kanama, nekrotik doku ve yabancı cisimlerin varlığ $\mathrm{da}^{\mathrm{a}}$ apse oluşumunu hızland1rır. Peritonit durumunda intestinal motilitenin azalmış olması ve yapışıklıklar apse oluşmasını hizlandıran bir faktördür. Tablo 4'de İAI'un şiddetini arttıran önemli faktörler sıralanmıştır. Perfore apandisitlerin erken safhalarında apse sadece periapandiküler bölgedeyken, geç kalınmış olgularda pürülan sıvı başta Douglas boşluğu ve parakolik mesafe olmak üzere karın içindeki tüm boşluklara yayılmış olabilir. İntraabdominal apseler subdiafragmatik ve subhepatik bölgelerde de sık görülmektedir.

Tablo 4. Intraabdominal infeksiyonun şiddetini arttıran faktörler.

Perforasyonun seviyesi

Barsak duvarındaki harabiyetin büyüklüğü

Laparatomiden önceki kontaminasyonun süresi

Ameliyatın acil şartlarda yapılması

Başka ek anomali ve ek travma olması

Cerrahi sahada nekrotik materyal ve yabancı cisim varlığı

Hematom

Hipotansiyon ve hipoperfüzyon

\section{İntraabdominal infeksiyonun klinik bulguları}

Ateş ve karın ağrısı, karın içi bir infeksiyonun en önemli klinik belirtileridir. İnfeksiyonun şiddeti arttıkça ve tedavi yapılmadıkça, ateş devam eder, kan sayımında lökosit yükselir ve diğer genel infeksiyon belirtileri kendini gösterir. İAI'un spesifik bir bulgusu olan karın ağrısının şiddeti, şekli ve lokalizasyonu karın içindeki infeksiyonun yerine göre farklılıklar gösterebilir. Bir perforasyon söz konusuysa sekonder peritonit bulguları tabloya hakim olacaktır. Ateş önce subfebril seyrederken infeksiyonun yayıl1mina paralel olarak artacaktır. Bu durumda taşikardi ve takipne görülebilecektir. İnfeksiyon karın içinde arttıkça ve yayıldıkça, akut karın olarak belirtilen daha ağır bir karın fizik muayene bulguları ortaya çıkar. Karın sert palpe edilir ve hassasiyet artar. Distansiyon solunumu etkileyecek kadar ciddi bir bulgu haline gelebilir. Defans, rebound, tahta karın gibi bulgular belirginleşir. Barsakların motilitesi bozulmuştur. Kusma olabilir, hafif bir ishal kendini gösterebilir veya kaka yapamama yakınması vardır.

Rektal muayene mutlaka yapılmalıdır. Rektumun boş olup olmaması, kan veya mukus varlığı, dışkının kıvamı, kokusu ve şekli İAİ'un nedeni hakkında önemli ipuçları verecektir. Ayrıca, pelvis boşluğundaki apsenin oluşturduğu kitle veya dolgunluk çok önemli bir bulgudur. Rektumun parmak ile palpasyonu ile intrapelvik kitle ve hassasiyet rahatlıkla hissedilebilir ve tanı konulabilir.

İlk bulgulardan olan ağrı ve hassasiyet tablonun ilerlemesiyle daha da artar, belirginleşir ve tüm karına yayılabilir. Akut apandisit durumunda ağrı göbek çevresinde başlarken apandisit bulgularının belirginleşmesiyle sağ alt kadrana lokalize olur. Perfore apandisit durumlarında ve İAİun yayılmasıyla ağrı tüm karına yayılabilir. Pariyetal peritonun inflamasyonu segmental somatik sinirlerin stimülasyonuna yol açarak ağrıyı başlatır ve karın kaslarının refleks rigiditesine neden olur. Visseral peritonun inflamasyonu da oluşan ödem ve lokal inflamatuar mediatörlerle paralitik ileus gibi barsağın fonksiyonel değişiklerine neden olabilir. $\mathrm{Bu}$ arada, barsakların bariyer görevi aksayabilir ve bakterilerin barsak duvarından translokasyonu ve infeksiyonun karın dışına taşınma durumu görülebilir ${ }^{(12)}$.

\section{Tanı yöntemleri}

Ateş ve ağrı gibi önemli fizik muayene bulgularına eşlik eden en önemli laboratuvar bulgusu lökositozdur. İmmatür polimorfonükleerlerin artması, yani sola kayma görülür. Ayrıca sedimentasyon gibi infeksiyon göstergesi diğer kan bulguları da tanıda yardımcı olacaktır. $\mathrm{Bu}$ arada immün sistemi zayıflamış ve sepsis bulgusu olan çocuklarda hipotermi ve lökopeni de olabileceği unutulmamalıdır.

Kan tetkikinde lökosit sayımı ve periferik yayma bulgularının mutlaka yapılması gerekir; ancak, lökositlerin karın içinde veya apse oluşumunda gösterilmesine yönelik detaylı tetkiklere gerek yoktur. Bazı merkezlerde, erişkin hastalar- 
da peritoneal lavaj ve buradaki beyaz küre say1mina bakılırken, bu metod çocuklarda genellikle uygulanmaz. Yine, akut inflamasyon durumlarında beyaz kürelerin işaretlenerek lökosit kümelerinin gösterilmesi tarif edilmiş olmakla beraber bu ve benzeri izotop çalışmaları pratik klinik çalışmalarda kullanılmamaktadır.

Düz karın grafileri İAI durumlarında mutlaka yapılması gereken radyolojik çalışmalardır. IAI'da vertebralarda akut skolyoz ve psoas kası görünüm değişikleri saptanabilir. İntestinal obstrüksiyonlarda gaz-sıvı seviyeleri veya genişlemiş barsak ansları önemli olabilirken, intestinal perforasyon durumlarında diyafram altında serbest havanın görülmesi tedaviyi hızlandıracak ve cerrahi kararı aldıracak (gecikilmiş olunsa da) önemli bulgulardır. Ayrıca apse içinde gazsıvı seviyesi veya gaz kabarcıkları da gözlenebilir. Nekrotizan enterokolit durumlarında barsak cidarında görülebilen pnömotozis intestinalis bulgusu ve portal sistemde hava kabarcı̆̆ı görünümü barsak civarında bakteri birikimini ve barsak duvarındaki nekrozu gösteren önemli bulgulardır. Duodenum ve rektum bölgelerinde patoloji düşünülüyorsa, kontrastlı radyolojik çalışmalar gerekebilir.

Günümüzde ultrasonografi, İAI'un her çeşidinde ve safhasında yapılabilecek, uygulaması paratik, hastaya külfeti az ve pahalı olmayan yararlı bir görüntüleme tetkikidir. Apsenin lokalizasyonu çok iyi tanımlandığı gibi, karın içindeki serbest sıvının miktarı ve karakteri hakkında bilgi verir. Ayrıca, özellikle yoğun bakım altındaki hastalarda, ultrasonografi eşliğinde perkütanöz aspirasyonla teşhise gitmek ve numune almak da mümkün olabilmektedir. Komputerize tomografi erişkinlerde İAİ tanısında ilk seçenek olarak önerilse de çocuklarda genellikle bu tetkike gerek kalmamaktadır. Çocuklarda yapılan bir meta-analizde ultrasonografinin apandisit tanısında duyarlığ 1 \% 88, özgüllüğü ise \% 94 olarak bulunmuştur. Aynı çalışmada komputerize tomografinin apandisitte tanısal değeri sirasıly \% 94 ve \% 95 olarak rapor edilmiştir ${ }^{(6)}$.

İAİ ve apsenin etkeni olan mikroorganizmanın tespiti tedaviyi doğru yapabilmek için çok önemlidir. $\mathrm{Bu}$ nedenle tanı konulduktan sonra veya bu sırada kültür alınmalı ve üretile- cek mikroorganizmaya etki edebilecek antibiyotiklerin saptanması yönünde gerekli mikrobiyolojik çalışmalar da gecikilmeden yapılmalıdır. $\mathrm{Bu}$ konuda aşağıda daha geniş bilgi verilmiştir.

\section{Cerrahi girişime bağlı infeksiyon}

Perfore apandisit ve diğer perforasyonlar gibi nedenlerle hastane dişında oluşmuş cerrahi tedaviyi gerektiren infeksiyonlar yanında, cerrahi girişime bağlı postoperatif dönemde ortaya çıkan infeksiyonlar da üzerinde durulması gereken önemli bir konudur. Toplumdan kazanılmış İAI'a göre hastanede kazanılmış İAI'lar genellikle daha ağır seyreder. Ciddi sonuçlara yol açabilecek bu hastane infeksiyonunun önlenmesi için gereken tedbirlerin zamanında alınması gerekir. Cerrahi alan infeksiyonları olarak adlandirılan bu komplikasyonlar, her infeksiyon gibi bakteriyel kontaminasyonun miktarına, virülansina ve hastanin direncine ve savunma sistemine bağlıdır. Ayrıca cerrahi teknik, kullanılan yabanc1 maddeler ve ameliyat ekibinin antisepsi kurallarına özeni de cerrahi infeksiyonları etkiler.

Ameliyattan sonraki 30 gün içinde ortaya çıkan ameliyat ile ilgili bu nozokomiyal infeksiyonlara cerrahi alan infeksiyonları denilir. Cerrahi alan infeksiyonları lokalizasyonuna göre ikiye ayrılır: İnsizyonel ve periton boşluğunda veya ilgili organda yerleşen. İnsizyonel cerrahi alan infeksiyonları yaranın derinliğine göre yüzeyel ve derin olarak ikiye ayrılır. Yüzeyel insizyonel infeksiyonlar deriyi ve deri altı dokusunu kapsar. Derin insizyonel cerrahi alan infeksiyonları ise, daha derindeki yumuşak dokuyu, kas yapılarını ve fasyayı içine alabilir. Ameliyat edilen organ veya karın boşluğunda oluşan cerrahi alan infeksiyonları ise ameliyat insizyonu dışında, girişim yapılan organı veya ameliyat edilen veya çıkartılmış olan o organın yerleşmiş olduğu karın içi boşluklarını kapsar ${ }^{(7,15)}$.

İntraabdominal infeksiyon sonrası ortaya çıkan bu infeksiyonlarda da etken mikroorganizmalar yukarıda söz edildiği gibi daha çok anaerob bakterilerdir.

\section{Intraabdominal infeksiyon tedavisi}

Her apse durumunda olduğu gibi, intraabdominal bir infeksiyon durumunda da tedavi 
kaynak kontrolü (drenaj) ve antibiyotik kemoterapisi (ampirik tedavi) olmak üzere iki eşgüdümlü tedavi içinde yapılır. İntraabdominal apsenin lokalizasyonuna göre uygun insizyonla laparatomi uygulanır. Yapılan eksplorasyonda apse aspire edilerek dışarı alınır. Bu arada mutlaka aerob ve anaerobların tespiti ve antibiyotik hassasiyeti için cerahat kültür numunesi alınır. Varsa eski dikiş materyalleri gibi yabancı cisimler çıkartılır, nekrotik materyal temizlenir. Apse lokalize ise yayılmaması için karın içi yıkama önerilmez. Apseye neden olan apandisit gibi etken patolojinin onarımı yapılır. Başka bir patoloji ve perforasyon olup olmadığ 1 incelenir ve gereken cerrahi düzeltme girişimi yapılır. Gecikilmiş perforasyon olgularında karın içi çok kirli ve infekte olabilir. Bu durumda yapilacak anastomozların iyileşmesi zor olabileceğinden ileostomi veya kolostomi gibi barsağı dışa ağızlaştıran geçici cerrahi girişimler söz konusu olabilir. Infectious Disease of Society of America ve Surgical Infection Society tarafından güncellenen erişkin ve çocuklardaki komplike intraabdominal infeksiyonların tanı ve tedavisi rehberinde kaynak kontrolü için aşağıdaki öneriler ortaya konulmuştur ${ }^{(18)}$ :

1. Kaynak kontrolü için infekte alanın drenajı, devam eden peritoneal kontaminasyonun diversiyon veya rezeksiyon ile önlenmesi ve anatomik ve fizyolojik fonksiyonların yeniden sağlanması gerekir.

2. Yaygın peritoniti olan hastalarda, işlem sırasında fizyolojik stabilitenin sağlanmas1 için önlemlere gerek duyulsa da, en kısa sürede acil cerrahi girişim yapılmalıdir.

3. Uygun olmasi durumunda apselerin ve diğer iyi sınırlı sıvı koleksiyonların perkutenöz drenajı cerrahi drenaja tercih edilir.

4. Minimal fizyolojik düzensizliği olan seçili hastalar ile iyi sınırlı infeksiyon odağ 1 olan hastalarda; periapandisyel veya perikolonik flegmon gibi, yakın klinik takip yapilabilme ihtimali varsa tedavi kaynak kontrolü yapılmaksızın antimikrobiyal tedavi ile yapılabilir.

Apse bölgesinin veya karın içinin iyice temizlendiğinden emin olunduktan sonra o böl- geye uygun diren(ler) yerleştirilir ve karın katlar1 kapatılır. Ameliyat sonrası pansumanlarda direnlerden gelen materyal takip edilir. İnfekte materyalin insizyona bulaşmamasına dikkat edilmelidir. Bazı ileri derecede olan peritonit durumlarında karın içinin tekrar temizlenmesi ve yeniden drenaj için yeni bir laparatomiye gerek duyulabilir.

Başlanan ampirik antibiyotik tedavisi kültür sonuçlarına göre tekrar değerlendirilir. Direnlerden gelen akıntının devamı durumlarında yeniden kültür alınarak antibiyotik kullanım stratejisinin yeniden düzenlenmesine gerek olabilir.

\section{Kültür için örnek alınması}

Laparatomi sırasında, karın içinde bir infeksiyon belirtisi görüldüğü zaman, antibiyotik tedavisini uygun yapabilmek için mutlaka kültür için numune alınmalıdır. Eğer generalize bir püy birikimi varsa yeterli cerahat kolayca alınabilir. Püy hemen görülememişse, karın içinde özellikle apse olabilecek bölgeleri eksplore edilmeli ve olası apse odağı bulunmalıdır. Apseleşmemiş bir infekte sekresyon birikiminde de bu sıvıdan numune alınmalıdır. Peritonit durumunda apse yoksa barsaklardan veya periton üzerinden sürüntü kültürü alınabilir. İleri inflamasyonlu ve nekrotik odaklar görülen durumlarda antibiyogram için doku örnekleri de alınabilir. Alınan numune çok iyi korunmalı, isim ve istek formu detaylı yazıldıktan sonra gecikilmeden mikrobiyoloji bölümüne gönderilmelidir. Anaerob bakteri olasılığı çok yüksek olduğundan normal vasat yanında, anaerob vasatlara da örnek alınmış olmalıdır. Bu nedenle İAİ olabilecek travma ve perforasyon gibi nedenlerle yapılacak ameliyat durumlarında anerob kültür alımı için her türlü hazırlığın önceden yapılmış olması gerekir. Surgical Infectious Society'nin 2010'da yayınladığ1 rehberde uygun mikrobiyal örnekleme için aşağıdaki prensipler belirlenmiştir ${ }^{(18)}$ :

1. Kan kültürlerinin rutin olarak alınması gereksizdir.

2. Eğer ampirik tedavi sik rastlanan anaerobik mikroorganizmalara karşı etkin ise, toplumdan kazanilan İAİ olan hastalarda anaerobik kültür alınması gerekli değildir. 
3. Yüksek riskli hastalarda, diğger hastalardan farklı olarak dirençli patojen bulunması daha sık olup, öncesinde antibiyotik alsalar bile, infeksiyon alanından rutin olarak örnek alınmalıdir.

4. İAİ odağından alınan örnek, klinik olarak infeksiyon olan bölgeyi temsil eden materyali içermelidir.

5. Kültürler bir örnekten alınmalı ve yeteri miktarda alınıp (en az $1 \mathrm{ml}$ sıvı veya doku, tercihen daha fazla), uygun şartlarda laboratuvara taşınmalıdır. Aerobik bakterinin uygun şartlarda bulunabilmesi için 1-10 ml sıv1 direkt aerobik kültür şişesine inoküle edilmelidir. Bunun yanı sıra $0.5 \mathrm{ml}$ sıvı laboratuvara Gram boyama ve endikasyonu varsa fungal kültür için gönderilmelidir. Eğer anerobik kültür isteniyorsa $0.5 \mathrm{ml}$ sıv1 veya 0.5 $\mathrm{ml}$ doku anaerob tüp ile taşınmalıdır. Alternatif olarak anaerobik bakterinin gösterilmesi için 1-10 ml sıvı direkt anaerobik sıvı kültür şişesine inoküle edilmelidir ${ }^{(18)}$.

Laparatomi ve apse drenajı dişında, girişimsel radyoloji deneyimi olan radyologların yardımıyla, görüntüleme yöntemlerini kullanarak perkütaneöz olarak kültür için numune alınması mümkün olabilmektedir ${ }^{(1)}$. Apandisit gibi mikroorganizmaların bilindiği İAİ durumlarında bazı cerrahlar kültür için numune almay1 göz ardı etseler de ${ }^{(5)}$, hastalığın ilerleyen safhalarında antibiyotik seçimimizde gerekeceğinden ${ }^{(19)}$, karın içinde infeksiyon odağı olan her durumda antibiyogram için numune alınması rutin olarak uygulanmalıdir.

\section{Intraabdominal infeksiyonlarda antibiyotik kullanım stratejisi}

Antibiyotik kullanımı diğer bölümlerde daha detaylı bir biçimde ele alınmakla beraber, bu bölümde de antibiyotik kullanım kurallarından İAI açısından kısaca söz etmekte yarar vardır. Değişmez kural her etken mikroorganizmaya antibiyogram sonuçlarına göre etkili olduğu bildirilen antibiyotiği vermektir. Ancak, özellikle ağır infeksiyon durumlarında, antibiyogram sonuçları hemen elimizde olmayacağı için, empirik olarak uygun düşündüğümüz antibiyotikle infeksiyon tedavisinin biran önce başlanması gerekmektedir. Bu nedenle İAI'larda pato- lojinin tespit edildiği gastrointesinal sistemin seviyesi ve lokalizasyonu kararımızda önemli parametrelerden biri olacaktır. Ayrıca, perforasyon ve peritonite neden olan hastalığın türüne ve derecesine göre etken olabilecek mikroorganizmaları daha önceden bilmek gerekir. Daha önce benzer hastalarda yapılmış olan antibiyogram çalışmaları ve o servisin hastane infeksiyon tarama sonuçları antibiyotik seçimimize yardimcı olacaktır.

Antibiyotik tedavisinin planlanmasında intestinal perforasyonun seviyesi çok önemlidir. Gastrointestinal sistemin alt seviyelerindeki perforasyona bağlı İI'da Enterobacter ve B.fragilis gruplarına etkili olan antibiyotiklerin verilmesi uygundur. Bu durumda hem aerobik hem de anaerobik mikroorganizmalara karşı olan antimikrobiyal ajanlar verilecektir. Yukarı seviyedeki lezyonlara bağlı infeksiyonlarda ise birinci jenerasyon sefalosporinler yeterli olacaktır. İAं için bu kriterlere göre antibiyotik seçimi hem tedavi, hem de profilaktik antibiyotik kullanımı için geçerlidir.

Surgical Infection Society tarafından İA'́da antibiyotik seçimi konusunda öneriler bildirilmiştir ${ }^{(18)}$. Bu öneriler in-vitro çalışmalar yanında, deneysel hayvan çalışmaları sonucunda ortaya çıkmış ve klinik çalışmalarla da doğrulanmış$\operatorname{tır}^{(18)}$. Bu bölümde yer alan ampirik tedavi önerileri 2010 yılında yayınlanan bu rehber göz önüne alınarak sunulmuştur ${ }^{(18)}$. Erişinlerde toplumda kazanılmış İAI'lar için ampirik tedavi önerileri şu şekilde özetlenmiştir:

1. Toplumdan kazanılmış İAÍnin tedavisinde kullanılan ampirik tedavinin enterik Gram negatif aerobik bakteriler ve fakültatif basiller ve enterik Gram pozitif streptokoklara karşı etkin olmalıdır.

2. Anaerobik basilleri kapsayan tedaviler obstriksiyon ve paralitik ileus varlığında, distal ince barsak, apandisiyal ve kolon kaynaklı infeksiyonlar ve daha proksimaldeki gastrointestinal perforasyonlarda kullanılmalıdir.

3. Erişkinlerde toplumda kazanılmış hafif-orta ciddi İI'larda ertapenem, moksifloksasin veya tigesiklin tek ajan tedavisi olarak veya metronidazol ile sefazolin, sefuroksim, seftriakson, sefotaksim, levofloksasin veya siprofloksasin kombinasyonları, anti-psödomonal 
aktivite için tercih edilir (A-I)(11,17) $($ Tablo 5).

4. Toplumda kazanılmış E.coli infeksiyonlarında yüksek direnç olması nedeniyle ampisilinsulbaktam tercih edilmez.

5. Daha az toksik olan ajanların en az eşit oranda etkin olduğu gösterildiğinden aminoglikozidler toplumda kazanılmış İAI'ların tedavisinde rutin olarak önerilmez.

6. Toplumda kazanılmış İAI'u olan hastalarda ampirik tedavinin enterokokları kapsaması gerekli değildir.

7. Toplumda kazanılmış İAI'u olan erişkin ve çocuk hastalarda Candida'ları kapsayan antifungal ampirik tedavi önerilmemektedir (A-I).

Çocuklarda toplumda kazanılmış İAİ için önerilen amprik tedavi stratejileri ise şu şekildedir:

1. Düşük ihtimalle komplike apandisit veya İAं şüphesi olan, ateş ve karın ağrısı şikayeti olan tüm çocuklarda geniş spektrumlu ajanlar endike değildir ${ }^{(18,19,20)}$.

2. Komplike İAI olan çocuk hastalarda özgül antimikrobiyal tedavi seçimi infeksiyonun kaynağına (toplum veya sağlık bakımı), hastalığın ciddiyetine ve bazı yaş gruplarına özgü güvenli antmikrobiyal ajanların kullanılması göz önüne alınarak yapılmalıdır.

3. Komplike İAİ olan çocuklarda kabul edilen geniş spektrumlu antimikrobiyal tedavi rejimi; aminoglikozidli, bir karbapenem (imipenem, meropenem veya ertapenem), bir betalaktam/beta-laktamaz inhibitör kombinasyonu (piperasilin-tazobaktam veya tikarsilinklavulanat) veya bir ileri jenerasyon sefalosporin (sefotaksim, seftriakson, seftazidim veya sefepim) ile metronidazolü içerir ${ }^{(8)}$.
4. Beta-laktam antibiyotiklere karşı ciddi reaksiyonu olan çocuklarda, siprofloksasin ve metronidazol veya bir aminoglikositli rejim önerilmektedir.

5. Nekrotizan enterokolit tedavisi sıvı resüstasyonu, intravenöz geniş spektrumlu antibiyotikler (antifungal ajanların dahil edildiği) ve barsak dekompresyonunu içerir. Barsak perforasyonu şüphesi olması durumunda acil laparatomi veya perkutanöz drenajla acil cerrahi girişim gerekir. Intraoperatif Gram boyama ve kültürler elde edilmelidir.

6. Nekrotizan enterokolitli yenidoğanlarda geniş spektrumlu antibiyotikler; ampisilin, sefotaksim ve metronidazol veya meropenem faydalıdır. MRSA şüpheli olgularda veya ampisilin dirençli enterokoklarda ampisilin yerine vankomisin kullanılabilir. Operasyon sırasında alınan örneklerin Gram boyama veya kültürlerinde fungal infeksiyon olması durumunda flukonazol veya amfoterisin-B kullanılmalıdır.

Erişin ve çocuklarda toplumdan kazanılmiş komplike İI'́da ampirik tedavi önerileri ${ }^{(17)}$ (Tablo 5) ve tedavide kullanılan ajanların dozla$\mathrm{ri}^{(2,16)}$ erişskin ve çocuklarda sırasıyla Tablo 6 ve 7'de gösterilmiştir.

Şiddetli infeksiyonlarda ise yukarıda anlatılan prensipler doğrultusunda farklı antibiyotik rejimleri gerekebilecektir. Hastanede kazanılmış İAI ve diğer cerrahi alan infeksiyonlarında bölgedeki mikroorganizma profiline ve antibiyogram sonuçlarına göre infeksiyon hastalıkları uzmanı ile beraber uygun antibiyotik seçimi yapılacaktır. Çocuklarda hastane kaynaklı İAI'da

Tablo 5. Komplike İAI'da (safra yolları kaynaklı infeksiyonlar hariç) ampirik tedavi önerileri ${ }^{(18)}$.

\begin{tabular}{|c|c|c|c|}
\hline \multirow[b]{2}{*}{ Rejim önerisi } & \multirow[t]{2}{*}{ Çocuklarda toplumda kazanılmış İAİ } & \multicolumn{2}{|c|}{ Erişkinlerde toplumda kazanılmış İAI } \\
\hline & & $\begin{array}{l}\text { Hafif-orta ciddi } \\
\text { (Perfore apandisit veya apse ve } \\
\text { diğer hafif-orta infeksiyonlar) }\end{array}$ & $\begin{array}{l}\text { Yüksek risk veya ciddi } \\
\text { (Ciddi fizyolojik düzensizlik, ileri } \\
\text { yaş veya immunsüpresyon) }\end{array}$ \\
\hline Tek ajan & $\begin{array}{l}\text { Ertapenem, meropenem, imipenem- } \\
\text { silastatin, tikarsilin-klavulanat, pipe- } \\
\text { rasilin-tazobaktam }\end{array}$ & $\begin{array}{l}\text { Sefoksitin, ertapenem, moksif- } \\
\text { loksasin, tigesiklin, tikarsilin- } \\
\text { klavulanat }\end{array}$ & $\begin{array}{l}\text { Meropenem, doripenem, } \\
\text { imipenem-silastatin, piperasilin- } \\
\text { tazobaktam }\end{array}$ \\
\hline Kombinasyon & $\begin{array}{l}\text { Seftriakson, sefotaksim, sefepim veya } \\
\text { seftazidim, her biri metronidazol ile } \\
\text { kombinasyon; gentamisin veya tobra- } \\
\text { misin metronidazol veya klindamisin } \\
\text { ile kombinasyon ve } \pm \text { ampisilin }\end{array}$ & $\begin{array}{l}\text { Sefazolin, sefuroksim, seftriak- } \\
\text { son, sefotaksim, siprofloksasin } \\
\text { veya levofloksasin, her biri met- } \\
\text { ronidazol ile kombinasyon }\end{array}$ & $\begin{array}{l}\text { Sefepim, seftazidim, siprofloksa- } \\
\text { sin veya levofloksasin, her biri } \\
\text { metronidazol ile kombinasyon }\end{array}$ \\
\hline
\end{tabular}


Tablo 6. Erişkinde komplike İAI tedavisinde kullanılan ilaç dozlart ${ }^{(18)}$.

\begin{tabular}{|c|c|}
\hline Antibiyotik & Erişkin dozaja $^{a}$ \\
\hline $\begin{array}{l}\text { Beta-laktam/beta-laktamaz inhibitör kombinasyonları } \\
\text { - Piperasilin-tazobaktam } \\
\text { - Tikarsilin-klavulanik asit }\end{array}$ & $\begin{array}{l}3.375 \text { g her } 6 \text { saatte } \mathrm{b}^{\mathrm{b}} \\
3.1 \mathrm{~g} \text { her } 6 \text { saatte, } 200 \mathrm{mg} / \mathrm{kg} / \mathrm{gün} * \mathrm{doz} \text { her } 6 \text { saatte olacak şekilde } \\
\text { bölünmüş ve ciddi infeksiyonda } 300 \mathrm{mg} / \mathrm{kg} / \text { gün } 4 \text { saatte olacak șekilde }\end{array}$ \\
\hline $\begin{array}{l}\text { Karbapenemler } \\
\text { - Doripenem } \\
\text { - Ertapenem } \\
\text { - Imipenem/silastatin } \\
\text { - Meropenem }\end{array}$ & $\begin{array}{l}500 \mathrm{mg} \text { her } 8 \text { saatte } \\
1 \mathrm{~g} \text { her } 24 \text { saatte } \\
500 \mathrm{mg} \text { her } 6 \text { saate veya } 1 \mathrm{~g} \text { her } 8 \text { saatte } \\
1 \mathrm{~g} \text { her } 8 \text { saatte }\end{array}$ \\
\hline $\begin{array}{l}\text { Sefalosporinler } \\
\text { - Sefazolin } \\
\text { - Sefepim } \\
\text { - Sefotaksim } \\
\text { - Sefoksitin } \\
\text { - Seftazidim } \\
\text { - Seftriakson } \\
\text { - Sefuroksim }\end{array}$ & $\begin{array}{l}1-2 \mathrm{~g} \text { her } 8 \text { saatte } \\
2 \mathrm{~g} \text { her } 8-12 \text { saatte } \\
1-2 \mathrm{~g} \text { her } 6-8 \text { saatte } \\
2 \mathrm{~g} \text { her } 6 \text { saatte } \\
2 \text { g her } 8 \text { saatte } \\
1-2 \mathrm{~g} \text { her } 12-24 \text { saatte } \\
1.5 \mathrm{~g} \text { her } 8 \text { saatte }\end{array}$ \\
\hline Tigesiklin & $100 \mathrm{mg}$ başlangıç dozu, $50 \mathrm{mg}$ her 12 saatte \\
\hline $\begin{array}{l}\text { Florokinolonlar } \\
\quad \text { - Siprofloksasin } \\
\text { - Levofloksasin } \\
\text { - Moksifloksasin }\end{array}$ & $\begin{array}{l}400 \mathrm{mg} \text { her } 12 \text { saatte } \\
750 \mathrm{mg} \text { her } 24 \text { saatte } \\
400 \mathrm{mg} \text { her } 24 \text { saatte }\end{array}$ \\
\hline Metronidazol & $500 \mathrm{mg}$ her 8-12 saatte veya $1500 \mathrm{mg}$ her 12 saatte \\
\hline $\begin{array}{l}\text { Aminoglikozidler } \\
\text { - Gentamisin veya tobramisin } \\
\text { - Amikasin }\end{array}$ & $\begin{array}{l}5-7 \mathrm{mg} / \mathrm{kg}^{\mathrm{c}} \text { her } 24 \text { saatte }^{\mathrm{d}} \\
15-20 \mathrm{mg} / \mathrm{kg}^{\mathrm{c}} \text { her } 24 \text { saatte }\end{array}$ \\
\hline Aztreonam & $1-2 \mathrm{~g}$ her $6-8$ saatte \\
\hline Vankomisin & $15-20 \mathrm{mg} / \mathrm{kg}^{\mathrm{e}}$, her $8-12$ saatte $^{\mathrm{d}}$ \\
\hline
\end{tabular}

${ }^{a}$ Dozlar normal renal ve hepatik fonksiyonlar içindir.

${ }^{b}$ P.aeruginosa infeksiyonu için dozaj $3.375 \mathrm{~g}$ her 4 saatte veya $4.5 \mathrm{~g}$ her 6 saatte olacak şekilde arttırlabilir.

c Aminoglikozid dozlar düzeltilmiş kiloya göre ayarlanmalıdır.

${ }^{d}$ Serum doz konsantrasyonu monitorize edilip, dozaj bireye göre ayarlanmalıdır.

${ }^{e}$ Vankomicinin başlangıç dozları total vücut ağırlığına göre yapılmalıdır.

"FDA onayladığı doz.

ampirik tedavi ile ilgili randomize kontrollü çalışmalar olmadığından erişkin verilerine göre ampirik tedavi planlanır ${ }^{(18)}$. Erişkinlerde önerilen sağlık-bakımı ilişkili İAİ ampirik tedavi önerileri Tablo 8'de yer almaktadır. Safra yolu kaynaklı İAI'larda önerilen ampirik tedavi önerileri de erişkin çalışmalarından elde edilmiştir. Tablo 9'da toplamdan ve hastaneden kazanılmış safra yolu kaynaklı İAI'ların ampirik tedavi önerileri gösterilmiştir(18).

\section{Antimikrobiyal tedavi süresi}

Komplike İAI'larda tedavinin ne kadar sürdürüleceği konusundaki karışıklıklar antimikrobiyallerin gereğinden uzun süre kullanılmasına ve direnç gelişimine neden olmaktadır. $\mathrm{Bu}$ nedenle İAI tedavi rehberleri çeşitli İȦ nedenleri ve özel durumlar için tedavi sürelerini belirlemeye çalışmıştır. Tedavi süresi ile ilgili aşağıda verilen öneriler erişkin verilerinden elde edilmiştir ${ }^{(18)}$ :

1. İnfeksiyon tespit edildiğinde antimikrobiyal tedavi yeterli kaynak kontrolünun zor olduğu durumlar dişında 4-7 gün ile sinırlıdır. Uzamış tedavi süresi sonuçların iyi olması ile ilişkili değildir ${ }^{(14)}$.

2. Tedavi amaçlı antimikrobiyal kullanımı aşağ1daki durumlarda 24 saaten fazla olmamal1dir ${ }^{(14)}$ :

a. Oniki saat içinde tedavi edilen travmatik veya iyatrojenik perforasyonlar.

b. Yirmidört saat içinde tedavi edilen gastroduodenal perforasyonlar.

c. Perforasyon olmayan akut veya gangrenöz apandisit.

d. Perforasyon olmayan akut ve gangrenöz kolesistitler.

e. Transmural barsak nekrozu; perforasyon, 
Tablo 9. Erişkinde safra yolları infeksiyonunda ampirik tedavi önerileri ${ }^{(18)}$.

\begin{tabular}{|c|c|}
\hline İnfeksiyon & Rejim önerisi \\
\hline Toplumdan kazanılmış orta-hafif ciddi akut kolesistit & Sefazolin, sefuroksim veya seftriakson \\
\hline Toplumdan kazanılmış ciddi akut kolesistit & $\begin{array}{l}\text { İmipenem-silastatin, meropenem, doripenem, siprofloksasin, levofloksasin veya sefepim; } \\
\text { her biri metronidazol ile kombine }\end{array}$ \\
\hline $\begin{array}{l}\text { Biliyoenterik anastamoz sonrası akut kolanjit } \\
\text { (ciddiyet fark etmeksizin) }\end{array}$ & $\begin{array}{l}\text { İmipenem-silastin, meropenem, doripenem, siprofloksasin, levofloksasin veya sefepim; } \\
\text { her biri metronidazol ile kombine* }\end{array}$ \\
\hline $\begin{array}{l}\text { Sağlık-bakımı ilişkili safra yolları infeksiyonu } \\
\text { (ciddiyet fark etmeksizin) }\end{array}$ & $\begin{array}{l}\text { İmipenem-silastatin, meropenem, doripenem, siprofloksasin, levofloksasin veya sefepim; } \\
\text { her biri metronidazol ile kombine*, vankomisin tüm rejimlere eklenebilir. }\end{array}$ \\
\hline
\end{tabular}

* Florokinolonlara karşı artan oranda E.coli direnci geliştiğinden, yerel antibiyogram sonuçları göz önüne alınmalıdır.

\section{KAYNAKLAR}

1. Akinci D, Akhan O, Ozmen MN et al. Percutaneous drainage of 300 intraperitoneal abscesses with long-term follow-up, Cardiovasc Intervent Radiol 2005;28:744-50. http:/ /dx.doi.org/10.1007/s00270-004-0281-4 PMid:16091990

2. Bradley JS, Sauberan J. Antimicrobial Agents: Principles and Practice of Pediatric Infectious Diseases, 3rd ed., Churchill Livingstone, Philadelphia (2008).

3. Brook I. Bacterial studies of peritoneal cavity and postoperative wound infection following perforated appendix in children, Ann Surg 1980;192:208-12. http: / /dx.doi.org/10.1097/00000658-198008000-00014 PMid:7406576 PMCid:1344855

4. Brook I. Microbiology and management of intra-abdominal infections in children, Pediatr Int 2003;45:123-9. http:/ /dx.doi.org/10.1046/j.1442-200X.2003.01701.x PMid:12709135

5. Çelik A, Ergün O, Özcan C, Aldemir H, Balık E. Is it justified to obtain routine peritoneal fluid cultures during appendectomy in children? Pediatr Surg Int 2003; 19:632-4

http:/ /dx.doi.org/10.1007/s00383-003-0978-5

PMid:14614631

6. Doria AS, Moineddin R, Kellenberger CJ et al. US or CT for diagnosis of appendicitis in children and adults? A meta-analysis, Radiology 2006;241:83-94.

http:/ /dx.doi.org/10.1148/radiol.2411050913 PMid:16928974

7. Drugas GT, Ognibene S, Pegoli W. Infection, “Oldham KT, Colombani PM, Foglia RP, Skinner MA (eds): Principles and Practice of Pediatric Surgery" kitabında s.239-51, Lippincott Williams and Wilkins, Philadelphia (2005).

8. Goldin AB, Sawin RS, Garrison MM, Zerr DM, Christakis DA. Aminoglycoside- based triple-antibiotic therapy versus monotherapy for children with ruptured appendicitis, Pediatrics 2007;119:905-11.

http:/ / dx.doi.org/10.1542/peds.2006-2040

PMid:17473090

9. Gorbach SL. Intestinal microflora, Gastroenterology 1971;60:1110-29. PMid:4933894

10. Kokoska ER, Silen ML, Tracy TF et al. The impact of intraoperative culture on treatment and outcome in children with perforated appendicitis, J Pediatr Surg 1999;34:749-53. http:/ / dx.doi.org/10.1016/S0022-3468(99)90368-8

11. Lin WJ, Lo WT, Chu CC, Chu ML, Wang CC. Bacteriology and antibiotic susceptibility of community-acquired intraabdominal infection in children, J Microbiol Immunol
Infect 2006;39:249-54.

PMid:16783457

12. Magnuson DK, Charles CL. Intra-abdominal infection and sepsis following trauma, "Fonkalsrud EW, Krummel TM (eds): Infectious and Immunologic Disorders in Pediatric Surgery" kitabında s.239-61, WB Saunders Company, Philadelphia (1993).

13. Marchildon MB, Dudgeon DL. Perforated appendicitis: current experience in a childrens hospital, Ann Surg 1977;185:84-7.

http:/ /dx.doi.org/10.1097/00000658-197701000-00014

14. Mazuski JE, Sawyer RG, Nathens AB et al. The Surgical Infection Society guidelines on antimicrobial therapy for intra-abdominal infections: an executive summary, Surgical Infec (Larchmt) 2002;3(3):161-73. http:/ /dx.doi.org/10.1089/109629602761624171 PMid:12542922

15. Mollit DL. Surgical infections, "Ziegler MM, Azizkhan RG, Weber TR (eds). Operative Pediatric Surgery" kitabinda s.161-77, McGraw-Hill Professional, New York, (2003).

16. Sauberan J. Systemic anti-infectives, "Bradly JS, Nelson JD (eds). Nelson's Pocket Book of Pediatric Antimicrobial Therapy, 16th ed." kitabinda s.108-24, AWWE, Buenos Aires (2006).

17. Solomkin JS, Mazuski JE, Baron EJ et al. Guidelines for the selection of anti-infective agents for complicated intra-abdominal infections, Clin Infect Dis 2003;37:9971005 .

http:/ /dx.doi.org/10.1086/378702

PMid:14523762

18. Solomokin JS, Mazuski JE, Bradley JS et al. Diagnosis and management of complicated intra-abdominal infection in adults and children: Guidelines by the Surgical Infection Society and Infectious Diseases Society of America, Clin Infect Dis 2010;50:133-64.

http:/ /dx.doi.org/10.1086/649554

PMid:20034345

19. Soyer T, Türkmen F, Akman $H$ ve ark. Apendek-tomi yapılan çocuklarda peritoneal sıvı kültürü alınacak olguların seçimi, Çocuk Cerrahi Derg 2007;21:120-3.

20. St Peter SD, Tsao K, Spilde TL et al. Single daily dosing ceftriaxone and metronidazole vs standard triple antibiotic regimen for perforated appendicitis in children: a prospective randomized trial, J Pediatr Surg 2008;43:9815 .

http:/ /dx.doi.org/10.1016/j.jpedsurg.2008.02.018 PMid:18558169 PMCid:3082440

21. Stone HH. Bacterial flora of appendicitis in children, $J$ Pediatr Surg 1976;11:37-42.

http:/ /dx.doi.org/10.1016/0022-3468(76)90167-6 